\title{
PEACE IN FIJI
}

\section{John D. Kelly and Martha Kaplan}

Much about ethnic Fijian culture is truly wonderful. But one of Fiji's most precious cultural resources is in grave danger. And this precious cultural resource is not part of ethnic Fijian culture. It is not kava circles, nor mataqalis and generalised reciprocity, nor tabua and the dignity of ritual hierarchy. This most precious cultural resource is non-violence, and while it has strong roots in the loloma (kindly love) that is the mana of Jehovah in Fiji, its widest and deepest roots in Fiji are Gandhian, and its most profound expression is now and long has been the forbearance and tolerance of the Indo-Fijians.

There are people in Fiji for whom mana e dina, 'mana is the truth'. What they see, and what they demand respect for, is the glory of power and status. And there are people in Fiji who seek and respect a truth whose highest realisations lie not in shakti, 'power', but in shanti, peace. There are lots of people in between, many respecting both forms of truth and some, neither. And these peoples cross-cut Fiji's ethnicities; one can find people whose lives are filled with love for a god of peace in any of Fiji's churches and in all of its seminaries, as readily as one can find them in the mosques, gurudwaras and temples, right down to the most remote of Ramayan mandalis or Sathya Sai centres.

The Gandhian tradition, that has done so much for Fiji, is rooted in religious love of god, peace and truth but it is also more than that. It brings a non-violent commitment to the truth into the heart of political processes like no other tradition of political ends and means. Satyagraha is the Sanskrit word Gandhi coined to name his political approach. Gandhi liked to translate it into English more than one way, sometimes as 'soul force', sometimes as 'insistence on the truth'. But a more literal Sanskrit 
translation is 'grasping the truth', 'holding on to the truth'. In Gandhi's hand the Christian and British tactics of righteous boycott and protest marches became dynamic vehicles of swaraj, 'self rule', as colonised Indians literally freed themselves from domination first of all by self-transformation, by realising their power to control their own expressions of consent and resistance. In Gandhian politics, the conscious satyagrahin, holding onto the truth, refusing to affirm untruth, chooses deliberately when and why to compromise and where and how to oppose the greatest threats and evils, especially when to sacrifice, not in anger but in duty.

It is not nearly well enough understood in Fiji, especially by outsiders to Indo-Fijian tradition, how many times Gandhian-inspired boycott, especially Indo-Fijian boycotts, have changed Fiji's history for the better, and shaped much of what is best about the Fiji of today. Long before the barristers sent by Gandhi, S.B. Patel and A.D. Patel, began their careers of good works in the islands, the Gandhian Bashisht Muni led the boycott in 1921 that clarified, once and for all, that the sugar industry could not continue on the basis of plantation-style labour contracts; CSR and government committed themselves to their experiments in Indo-Fijian small farming, much to Fiji's benefit as both profits and living standards were raised. The boycott of the Legislative Council and call for 'common roll' voting, begun in 1929 by the Fiji Indian National Congress, led by Vishnu Deo, was doomed in an empire whose racism was steadily increasing, but uncompromisingly raised the question of when and how Fiji could reach past the barriers of race, a question many in Fiji still need to face up to. And the cane boycotts of the 1930s and 1940s - yes, we would argue absolutely, even the bitter boycott of 1943, deliberately provoked and prolonged by a British governor reckless in his hatred of A.D. Patel and Swami Rudrananda - not only led Fiji to greater justice in industrial relations, but also (and even though so many have painted them matters of race and loyalty to nation) continued the process of finding, in economic truths, the way out of Fijis heritage of colonial race difference and antagonism. All cane growers get the same price; garment workers' and other workers' wages respond far less to race than to markets, and the whole nation is hurt when government planning and contracting are corrupt. 
You don't need us to tell you who George speight is, what damage has been done to Fiji's economy and democracy by the cascade of terrible events that have followed on his rank and ugly opportunism. You don't need us to tell you how tragic is the decision of Bainimarama and the military to take it upon themselves to write a new Constitution. But there is something that perhaps we can observe, thinking comparatively and anthropologically about the Indian diaspora and the global politics of the last century. You probably already know that Fiji's 1997 Constitution was a progressive mix of globally informed multicultural democratic vision and locally attuned, pragmatic compromise. You may hope, as we do, that sooner or later, in one form or another, Fiji will see not merely its return but the arrival of a Constitution that better enshrines its guiding principles. But there is more to fear than its loss in the meantime.

While suva is enveloped in a cacophony of discord, with ominous streaks and smears of disorderly violence, another cane boycott has far more quietly and non-violently begun in the west and north. As usual, the threats have come from the men of mana, not from the people wronged, not from those who voted for the cherished People's Coalition government now destroyed and held hostage, not from the people whose situation is now so precarious on the lands where they have lived their lives. What comes from them is not a threat, but a reality of noncooperation. The army, now, won't allow meetings. It won't allow the boycott to have its leaders even to state its terms. Thus the truth this boycott insists upon remains inchoate, spontaneous and intense. Together with international economic boycotts it mounts an economic pressure, too, that is intense. But we promised a comparative perspective. And it is ominous.

Fiji is not only a nation that should take pride in the great gifts it has gained from its Gandhian heritage. It is also one of the last outposts of Gandhian-inspired political action where there is still a general public committed to a politics of non-violent boycott in response to injustice. It might be the last outpost, where Gandhian protests have not been answered by organised violence. Just about everywhere else with a Gandhian history, of whatever form of cultural transmission, from our 
own USA's civil rights movements to India itself, non-violent self-sacrificers have been overcome, at times, by the ruthlessness and contempt of their foes. To suffer non-violently, insisting on the truth is pointless, if the truth is that you have enemies who do not care about your suffering.

Ethnic Fijian leaders in quest of greater mana may decide, this year, to seek it by coercing or dispossessing their non-violent neighbours. There is even talk from some quarters of using the army to cut the cane and break the cane harvest boycott, something that has never happened before in Fiji. Or the suffering of the farmers may simply be ignored. In the long run, however, Fiji's current leaders may discover that their mana was actually underwritten in part by the forbearance of the lovers of shanti. If the current military government violently destroys a tradition of peaceful protest that has helped make Fiji great, or if they allow acts of violence to go unpunished, they will lose far more of their own world than they could have imagined possible.

We hope for a peaceful solution. In fact, we can envision the process, as in 1987 to 1997, leading to more perfect union, and possibly on a much shorter clock, given the skepticism about this coup in the outside world. But we are also aware of other possibilities, and fear for what Fiji is already losing, not least with every new passport issued: not ethnic Fijian culture, which has never really been threatened, but Indo-Fijian faith in a politics of peace and truth for Fiji. 